\title{
MARAZM CZY WYKORZYSTANA SZANSA?
}

\author{
SPOŁECZNOŚCI LOKALNE WOBEC \\ DZIAŁAŃ SAMORZĄDÓW LOKALNYCH \\ W WARUNKACH CZŁONKOSTWA POLSKI \\ W UE I DECENTRALIZACJI KRAJU
}

ABSTRACT Fatigue or fulfilled opportunity? Local communities facing local self-government policy in light of Poland's EU membership and decentralisation The article below is a response to the question about consequences of two milestones of contemporary Polish history to the local communities. These two events of the latest history are significant: 15 years since the territorial reform and introduction of three-leveled regional authority and the $10^{\text {th }}$ anniversary of Polish membership in the European Union. Based on the researches and replies to the questions of the respondents we are allowed to address an issue not only of potential successes and benefits connected with the mentioned events but also all failures, which create discomfort in existence of local communities in their homeland. The author presents an attitude of citizens of 6 Polish municipalities to the European Union as well as the most important advantages and disadvantages of Polish participation in the structures of the EU (connotations to the EU, satisfaction from drawdown European funds and the matter of introducing common currency to Polish economics). Data from the surveys will be confronted with the perspective of respondents to low public administration, predominantly in municipalities (an ability to absorb EU funds with all the consequences such as debts, decisions consulting, satisfaction from civil service along with the most common pathologies). 
Słowa kluczowe: samorząd, administracja publiczna, gmina, integracja europejska, UE, EURO, fundusze UE

Keywords: self-government, public administration, commune, European integration, EURO, EU funds

\section{WSTĘP}

W minionym roku (2014) minęło dziesięć lat, od kiedy Polska stała się członkiem Unii Europejskiej. Minęło jednak również piętnaście lat od przeprowadzenia przez rząd premiera Jerzego Buzka reformy ustroju terytorialnego Polski i wprowadzenia trójszczeblowego systemu samorządu terytorialnego. Należy zauważyć, że jest to więc chyba dobry czas, aby zastanowić się, czy polskie samorządy (w szczególności gminy i powiaty) udźwignęły ciężar tej odpowiedzialności. Jest to bowiem odpowiedzialność dwojakiego rodzaju:

Po pierwsze, związana jest z absorbcją środków pomocowych UE i generalnie szansami, jakie dało wstąpienie Polski do tej organizacji. Warto przy tym pamiętać, że lata 2007-2013 były też pierwszym okresem pełnego uczestnictwa naszego kraju w wieloletnich ramach finansowych $\mathrm{UE}^{1}$.

Po drugie, warunkowana jest konsekwencjami daleko idącej reformy ustroju terytorialnego kraju z 1999 r. i związanego z nią procesu decentralizacji. To ona zwłaszcza miała uczynić społeczności lokalne prawdziwymi gospodarzami „małych ojczyzn”, a wybierane przez nie władze gmin i powiatów wykonawcami ich woli².

W niniejszym tekście autor, powołując się na przeprowadzone badania, podejmie próbę analizy materiału empirycznego zebranego w ramach projektu „Polska lokalna wobec integracji europejskiej - dekada doświadczeń” realizowanego przez zespół pracowników Instytutu Europeistyki Uniwersytetu Jagiellońskiego ${ }^{3}$. Przeanalizowane więc zostaną takie kwestie, jak stopień zadowolenia mieszkańców gmin zarówno z członkostwa Polski w UE, jak i z rządów wybieranych przez siebie liderów lokalnych. W związku z powyższym interesować nas będą następujące zagadnienia:

1. Stosunek ankietowanych do integracji europejskiej, a w szczególności:

a) zadowolenie z członkostwa Polski w Unii Europejskiej;

b) dysonans między euroentuzjazmem a EUROsceptycyzmem4;

c) zadowolenie z poziomu pozyskania i wykorzystania przez samorządy funduszy europejskich.

Zob. np.: Polskie 10 lat w Unii - raport, Ministerstwo Spraw Zagranicznych RP, Warszawa 2014.

2 Zob.: M. Kulesza, Transformacja ustroju administracyjnego Polski (1990-2000), „Studia Iuridica” 2000, t. 38, s. 79-80.

3 Projekt „Polska lokalna wobec integracji europejskiej - dekada doświadczeń” finansowany przez Narodowe Centrum Nauki (2011/03/B/HS6/01163).

4 Na potrzeby niniejszego tekstu, ilekroć mowa będzie o wspólnej europejskiej walucie, jej nazwa pisana będzie zawsze wielkimi literami (EURO). 
2. Stosunek ankietowanych do władz lokalnych, a w szczególności:

a) zadłużenia samorządów lokalnych w kontekście inwestycji współfinansowanych z funduszy UE;

b) poziomu otwarcia samorządu (urzędników) na obywatela i skali konsultacji podejmowanych przez władze samorządowe decyzji;

c) zadowolenia z działalności administracji samorządowej na poziomie gminy (problem biurokracji, systemu pomocy socjalnej i społecznej oraz tzw. „układów" i lokalnych patologii z nimi związanych).

\section{STOSUNEK SPOŁECZNOŚCI LOKALNYCH DO PROCESU INTEGRACJI EUROPEJSKIEJ I UNII EUROPEJSKIEJ}

Stosunek Polaków do integracji europejskiej od początku transformacji systemowej był zawsze bardzo pozytywny, a związane to jest zarówno z niezwykle krytycznym wspomnieniem eksperymentu zwanego „demokracją ludową" i gospodarką centralnie planowaną, jak również z generalnym kierunkiem polityki zagranicznej państwa, akceptowanym przez większość sił politycznych kraju. Świadczą o tym nie tylko przeprowadzone przed wejściem Polski do UE badania naukowe w tym temacie, lecz także badania ankietowe Centrum Badań Opinii Społecznej5. Co warte podkreślenia, zauważalny jest nawet wzrost tego poparcia, gdy porównamy dane sprzed akcesji Polski do europejskich struktur integracyjnych i z czasu pełnego w nich uczestnictwa.

W okresie bezpośrednio poprzedzającym wejście Polski do UE poparcie to oscylowało między 58\% a 69\%, tak aby w maju 2004 r. osiągnąć stopień aż $71 \%{ }^{6}$. W ciągu dziesięciu lat członkostwa ten entuzjastyczny wręcz stosunek do uczestnictwa naszego kraju w europejskich strukturach integracyjnych nie tylko utrzymuje się niezmiennie na bardzo wysokim poziomie, ale wręcz wzrasta, dochodząc momentami do wyniku 89\% (w kwietniu 2008 r. oraz w marcu 2014 r. $)^{7}$. Co trzeba w tym miejscu zauważyć, trendu tego nie odwrócił nawet kryzys ekonomiczny panujący w UE od 2009 r.

Mając na względzie to wysokie poparcie dla integracji europejskiej, trudno nie wspomnieć jeszcze o ambicjach Polaków. Bez wątpliwości stwierdzić można, że członkostwo kraju w UE miało dla nas być dowodem, że mimo wszystkich niedoskonałości i ułomności polskiego państwa chcemy jako społeczeństwo dołączyć do „europejskiej

Zob.: Polska lokalna wobec integracji europejskiej, red. Z. Mach, D. Niedźwiedzki, Kraków 2001.

6 CBOS, Komunikat z badań, BS/115/2004, Stosunek do cztonkostwa w Unii Europejskiej i pozycja Polski wzjednoczonej Europie, Warszawa, VII 2004, s. 2, Tabela 1. W referendum akcesyjnym, które odbyło się 7 i 8 VI 2003 r., 77\% głosujących poparło wejście Polski do UE. Zob.: Obwieszczenie Państwowej Komisji Wyborczej z dnia 9 czerwca 2003 r. o wyniku ogólnokrajowego referendum w sprawie wyrażenia zgody na ratyfikacje Traktatu dotyczacego przystapienia Rzeczypospolitej Polskiej do Unii Europejskiej, Dz. U. 2003, nr 103, poz. 953.

7 CBOS, Komunikat z badań, BS/66/2008, Bilans czterech lat integracji Polski z Unią Europejska, Warszawa, IV 2008, s. 3, Tabela 1; CBOS, Komunikat z badań nr 52/2014, 10 lat cztonkostwa Polski w Unii Europejskiej, Warszawa, IV 2014, s. 6, Tabela 1. 
rodziny" i będziemy w stanie pokonać obiektywne przeszkody związane z nieprzystosowaniem do tzw. zachodnich wartości, stylu życia i postaw. Spełnienie owych mitycznych „zachodnich standardów” miało być dla nas dowodem na skok cywilizacyjny, jakiego jesteśmy w stanie dokonać ${ }^{8}$.

Można założyć, że wzrost liczby zwolenników członkostwa Polski w UE powiązany jest $\mathrm{z}$ widocznymi już w naszym kraju inwestycjami, które są efektem uruchomienia środków pomocowych w ramach unijnych funduszy strukturalnych. Potwierdzają to zresztą wypowiedzi zdecydowanej większości respondentów, których pierwsze skojarzenie z Unią Europejską odnosi się właśnie do otrzymywanych z UE środków finansowych i inwestycji (głównie infrastrukturalnych), które widzą na co dzień w swoim otoczeniu. W wypowiedziach respondentów widać też wyraźnie połączenie tych skojarzeń z ostatnimi kilkoma latami, kiedy Polska była już członkiem UE. Tak więc na pytanie o konotacje z UE i zachodzące ostatnio zmiany w gminach i powiatach padają bardzo zdecydowane i krótkie odpowiedzi.

Unia kojarzy mi się z pomoca dla naszego kraju, z inwestycjami, które sa tutaj prowadzone. Unia to dla mnie dotacje. W naszej gminie dość dużo się tego realizuje, więc dla mnie Unia to przede wszystkim organizacja pomocowa (L/G/03).

Jasne. Przecież daja [UE - M.N.] pieniądze i my tych pieniędzy potrzebujemy. Teraz bardziej niż kiedykolwiek. Ten caty kryzys niszczy takie mate miejscowości. Przede wszystkim tutaj. Bo tutaj mato kto już teraz inwestuje i dobrze, że jeszcze od czasu do czasu Unia cośsypnie (NR/B/10).

Jeśli byśmy spojrzeli na te ostatnie dziesięciolecie, to myśle, że każdy mieszkaniec zauważy, że sa zmiany. Przede wszystkim rozwój związany z uzyskiwaniem funduszy unijnych. Od 2007 r. dzięki temu, że gmina mogta pozyskiwać fundusze, mamy przede wszystkim realizowane różne projekty, choćby w szkotach, to, co się dzieje (NR/J/04).

No kasa, kasa. Przeptyw pieniędzy i możliwości siegnięcia po nie. To jest wielkim plusem, że dzięki pozyskanym środkom możemy się rozwijać. I tak jak powiedziatam na początku, że ja dzięki tym środkom widzę wielki plus (NR/L/01).

$Z$ finansami, z funduszami, generalnie ze sprawami ekonomicznymi. Generalnie stychać tylko, ile Unia daje, na co daje i to się w sumie tylko styszy, więc nawet trudno bytoby mi powiedzieć, czym jeszcze Unia się zajmuje. [...] Tak, dużo na tym zyskaliśmy. [...] gdyby nie pieniadze z UE, tej budowy przystowiowej by nie byto, nic by nie byto. Pieniadze z Unii daty nam zastrzyk, który byt nam bardzo potrzebny (Z/Z/08).

To sa fundusze, doptaty, inwestycje tak ogólniej. Wydaje mi się, że wszystko, co się ostatnio dzieje w Polsce, to Unia, Unia, Unia. Ciężko cośdzisiaj bez niej zrobić (Z/W/01).

$\mathrm{Z}$ powyższych wypowiedzi nie należy wyciągać wniosku, że Polacy są wobec Unii Europejskiej całkowicie bezkrytyczni. Potrafią dostrzec również pewne niedogodności związane z członkostwem i nawet jeśli nie znają szczegółów, to przynajmniej zdają sobie

Zob.: M. Natanek, D. Niedźwiedzki, Kompetencje spoteczeństwa polskiego w zakresie kultury europejskiej, czyli o nieprzygotowaniu do integracji z Europa, [w:] Kregi kompetencji i perspektywy poznawcze, red. J. Goćkowski, P. Kisiel, Kraków 1999, s. 325-343; ciż, Kulturowe kompetencje Polaków a integracja europejska, [w:] Integracja europejska w oczach Polaków, red. Z. Mach, Kraków 1998, s. 51-66, Studia i Analizy Fundacji Międzynarodowe Centrum Rozwoju Demokracji, 5. 
sprawę z tego, że proces integracji wymaga nadal od Polski dostosowania norm prawnych, pewnych działań zmieniających dotychczasowe ich przyzwyczajenia (np. ostatnio problem segregacji śmieci) i być może nawet niosących zagrożenia (uzależnienie).

$\mathrm{Z}$ rozmów wynika więc, że o ile respondenci nie mają nic przeciwko członkostwu Polski w UE, to jednak nie wszystkim podobają się mechanizmy jej działania, których konsekwencją jest np. dopuszczenie na polski rynek tańszych towarów z zagranicy lub też różnego rodzaju niezrozumiała dla niektórych grup społecznych pomoc finansowa (często pojawia się kwestia dopłat dla rolników). Bez względu na te uwagi, również w takich przypadkach rachunek zysków i strat bezwzględnie przemawia według nich na korzyść członkostwa.

Na plus zmienito się wszystko. Na minus niewiele. No, może trochę się za bardzo uzależniliśmy od tego, że UE daje, że te pieniadze sa. Nie wiem, co by byto, gdyby nagle UE przestata istnieć, a za tym przestalibyśmy dostawaí te ogromne fundusze. Chyba już kompletnie Polskę opanowatby jakiśs straszny zastój i bieda. Ogrom pieniędzy, który zostat dostownie wttoczony $w$ ten region, jest bezprecedensowy. Zostaty wybudowane drogi, rozbudowane szkoty, hale sportowe (L/G/05).

Bo to jest Zachód [UE - M.N.], bo daja pieniadze, trochę nam pomagaja, trochęprzeszkadzaja, ale generalnie wychodzi z tym wszystkim na plus. Ponoć więcej od nich dostajemy, niż wptacamy, więc póki co nie jest źle. Przynajmniej Polska się buduje, cośsię buduje (NR/D/03).

Ogólnie jeżeli chodzi o miejscowości, widać pewne zmiany, [...] powstają place zabaw, boiska, chodniki, staramy się bardziej dbać o wygląd tych miejscowości. O, na pewno jest widoczne. [...] Wydaje mi się, że należy to mimo pewnych braków ocenić pozytywnie. Naprawdę wiele zmienito się na korzyść, więcej jest plusów, wyraźnie. Gtównym nierozwiązanym problemem pozostaje bezrobocie, ale to trudno taczyć z Unia Europejska, to jest spuścizna po dawnych czasach. Powstaje lepsza infrastruktura, widać remonty, poprawę wielu aspektów życia (NR/J/03).

[...] bo jakbyśmy nie weszli do UE, bytaby generalnie masakra. Polska zostataby taka wyspa pośrodku tych wszystkich bogacacych siępaństw. Nie dalibyśmy sobie rady bez UE i ona też bez nas miataby pewnie troche gorzej. No jesteśmy, jakby nie byto, jakimśr rynkiem zbytu. Idę do hipermarketu i kupuje nie warzywa z Polski, bo sq drogie, tylko powiedzmy te z Hiszpanii albo Holandii. Takie mamy czasy i nic na to nie poradzimy. Musimy się dostosowywać do trendów, a dzisiaj trendem jest, by sięjednoczyć, więc sięjednoczymy. [...] Ja się tam tą integracja za bardzo nie podniecam (Z/Z/11).

Spora grupa respondentów bardziej krytycznych wobec zachodzących procesów zwraca uwagę na celowość niektórych działań związanych z absorbcją środków UE i bardzo trzeźwo potrafi wskazać i ocenić mechanizmy, które się im nie podobają. W tej materii uwypuklane są najczęściej dwie powiązane ze sobą sprawy. Po pierwsze, wszechobecne rozdawnictwo pieniędzy unijnych „na siłę”, a po drugie, fatalny system szkoleń opłacanych z funduszy europejskich, który ich zdaniem jest nie tylko sposobem na tzw. wyciskanie brukselki, ale też tworzenie patologicznych układów towarzysko-zawodowych. Respondenci tacy bardzo negatywnie wypowiadają się zwłaszcza o tego typu kursach, mówiąc, że są to pieniądze źle wydawane, a same szkolenia są często 
celowo droższe, żeby mogły zarobić na tym firmy szkoleniowe, cateringowe czy hotele. Uważają także, że jeśli pieniędzy nie da się dobrze spożytkować, to nie należy ich wydawać w ogóle lub przeznaczyć je na inne cele9 . Co ciekawe, narzekają na to również sami urzędnicy, którzy nie rozumieją systemu szkoleń organizowanych przez firmy zewnętrzne zamiast przez urzędy wyższego szczebla.

[...] mnie się kojarzyta [UE - M.N.] bardzo dobrze, ale musze przyznać, że w tej chwili mam obojętny stosunek do tego. Musze przyznać, że bytem wielkim euroentuzjasta. Teraz stwierdzam, że jak się z tym wszystkim trochę blizej zapoznatem, to to jest taki socjalistyczny wynalazek, ta Unia. Po pierwsze, ja bym nie dat nikomu żadnych doptat. Niech każdy normalnie pracuje na swoje i za dobrą prace niech ma dobrą ptacę. Co to w ogóle jest, że 55-letni rolnicy dostaja jakieś tam renty strukturalne albo kupuja ciagniki z klimatyzacja za dofinansowanie z Unii. Krótko więc, Unia Europejska to taka fajna zabawka i wielu się przy niej nieźle bawi. Najlepsze, że ci, co krzycza o suwerenności i jaka ta Unia jest "be”, to pięknie wyciagają tapki po pieniądze wtaśnie od tej Unii jako pierwsi (SZ/SZ/16).

[...] Wtaśnie te szkolenia $i$ inne próby aktywizacji spoteczeństwa. Nie mówię, że idea jest zta, ale jest to źle wykonywane. Przychodzi ktoś spoza regionu, kompletnie nie zna realiów, opowiada jakieś rzeczy, które albo wiemy, albo sie nie przydaja, i dostaje za to relatywnie duże pieniądze. Zamiast wydawać pieniądze na cateringi, niech lepiej zaczna dożywiać dzieci w szkotach. Jest to ogromny problem $w$ tym regionie (L/BK/02).

Po co wyjeżdzać do Zakopanego albo do jakiegoś zamku w czymś tam, żeby postuchać pare sesji nt. oceny zadowolenia petenta. Widać, że te szkolenia sa przeinwestowane. To znaczy, ja nie mam co narzekać, bo przecież mito mi, że jest tak tadnie i wogóle, i że wydaje się na mnie tyle pieniędzy, ale po co? Niech dadza te pieniadze ludziom potrzebujacym, dzieciom na ksiazkki, a nie firmom, które w patacach robia szkolenia za ogromne pieniądze i to $w$ sumie za nasze pieniadze (L/G/01).

Ja przynajmniej raz w miesiacu jadę na jakieśszkolenie za unijne pieniądze. Mam wynajęty pokój w hotelu, przyjeżdzaja jakieś psycholożki i gadają. Co z tego, że to nawet tadne kobitki są, skoro nic mnie już nie moga nauczyć i zawsze gadaja to samo. Dyplomów to mam chyba $z 10$ o ukończonych szkoleniach, ale po co to? [...] Tak à propos tych szkolen, to kiedyśzadzwonita do mniepani, że jest szkolenie z pierwszej pomocy za pieniadze unijne... $i$ co się okazato? Że ja wcale na tym szkoleniu nie muszę być. Wystarczy, że doptacę i sobie klikne pare razy w Internecie i już mam szkolenie zaliczone (SZ/SZ/16).

Tylko niewiele spośród wypowiedzi respondentów można uznać za wyraźnie negatywne i antyunijne, a te mają zazwyczaj wyraźny kontekst ideologiczny, związany z poglądami politycznymi osób je wypowiadających oraz dostępem do konkretnych mediów i źródeł informacji („Gazeta Polska”, „W Sieci”, „Do Rzeczy” itp.). Często też po dopytaniu okazuje się, że te antyunijne wypowiedzi związane są raczej z wewnętrzną sytuacją polityczną w Polsce i działalnością polskich władz, i to zarówno szczebla centralnego, jak i terenowego. Jeżeli więc krytykowana jest sama idea integracji europejskiej, to raczej dlatego, że aktualnie rządzący krajem politycy (koalicja PO-PSL),

Często w przypadku takiej krytyki respondenci prosili o wyłącznie sprzętu rejestrującego rozmowę, a następnie przyznawali, że przeprowadzanie szkoleń jest sposobem na dorobienie dla kolegów i znajomych, np. NS/NS/04 lub L/G/01. 
jak i większość politycznego establishmentu są wyraźnie proeuropejscy ${ }^{10}$. Trudno też nie przypomnieć, że cytowane poniżej krytyczne wypowiedzi zdarzają się także dlatego, że wielu polskich polityków obarcza UE winą za niepopularne reformy i zmiany prawne.

Unia jest chorym wymystem socjalistów powojennych. [...] Dla mnie ta cata Unia jest jednym wielkim przekrętem. Nie daję się omamić tym wszystkim pożal się Boże Europejczykom, wkręcić w ta cata Unię. [...] Dla mnie to ona generalnie szkodzi, nie dlatego, że jest, tylko dlatego, że robi z nas idiotów. [...] A to w taki [sposób], żepowoli wyprzedajemy się. Ar po arze, nasze najlepsze ziemie, że Unia daje na razie pieniadze, a później będzie cośna pewno chciata w zamian. Ja Panu mówię, że to jest powolne wyprzedawanie duszy [...]. To wszystko skupia się wokót warszawki i kolegi Tuska (NR/B/08).

Dla mnie niedobrze, [że Polska weszła do UE - M.N.]. Dla mnie Unia, prosze Pana, to podwyżki cen żywności, to kryzys, to jakieś durne regulacje, niepotrzebne [wulg.] sie w sprawy Polski (NS/NS/03).

[Unia kojarzy się - M.N.] Zazwyczaj z funduszami, ale też z pewnym takim zbiorowym nawotywaniem do poglądów europejskich, do takiej bylejakości kulturowej i chrześcijańskiej. Każe się nam być jednym i tym samym, integracja chyba też ma to na celu, żeby zrobić z nas takie europejskie zombie. Robimy to, co Unia nam każe, nie zawsze dla nas jest to dobre. [...] Na pewno pieniadze, jakie dostajemy od UE. To też nie jest tak kolorowo, jak rysuje nam pan Tusk, że dostajemy tak bardzo dużo, że Polska najbardziej korzysta z Unii, bo są kraje typu Niemcy, które korzystaja z tego o wiele bardziej. No ale ja nie odmawiam tego, że dostajemy te pieniadze. Dobrze jest, że mamy gtos $w$ Unii, ale ten gtos jest za staby. Nasza polityka zagraniczna jest żatosna, a Sikorski jest, co tu dużo mówić, osobą nieodpowiednia na stanowisku szefa MSZ. Jest stużalczy w moim mniemaniu. To samo zreszta pan Tusk, który w porównaniu do prezesa Kaczyńskiego jest politykiem stabym i miatkim. Ten rząd nie ma wizji Europy i to jest jego gtówny problem (Z/B/01).

Strasznie nam wszystko narzuca [UE - M.N.]. Jak idzie się na rynek, to rolnicy co chwila się skarża, że UE im żyć nie daje, że wcześniej lepiej się handlowato. Nawet za komuny. [...] Ja Panu powiem tak, mi UE kojarzy się trochę z takim oprawczym, jeżeli można tak to nazwać, zachowaniem. Oni nas tak kolonizuja trochę. UE tak nas rozpuścita. No i co z tego, że dają nam te pieniądze, my się trochę tak sprzedajemy im za pieniądze, prostytuujemy (NS/NS/03).

Analiza materiału empirycznego wskazuje, iż drugą w kolejności najczęstszą odpowiedzią dotyczącą skojarzeń z UE jest swoboda przepływu osób. Zaznaczyć jednak trzeba wyraźnie, że jest to wolność postrzegana przez Polaków bardzo wąsko jako swoboda przemieszczania się, a przede wszystkim możliwość podejmowania legalnej pracy w państwach UE. Zasada ta jest rozumiana bowiem przez respondentów au rebours, zamiast więc myśleć w kategoriach „to, że mogę tam zamieszkać, powoduje, że mogę tam również podjąć pracę”, zdecydowana większość pytanych rozumuje odwrotnie: „skoro tam pracuję, to przecież muszę tam mieszkać”. Bez względu jednak na sposób

10 Wszystkie cytowane wywiady przeprowadzane były w czasie, kiedy Prezesem Rady Ministrów był jeszcze Donald Tusk i to personalnie w stosunku do niego kierowane były najczęściej słowa krytyki. 
pojmowania tej swobody, ta wyraźna korzyść jest najczęściej konfrontowana z masową emigracją zarobkową, z jaką mamy do czynienia po wejściu Polski do UE.

Mało kto wspomina więc o swobodzie podróżowania bez konieczności sprawdzania dokumentów, ponieważ okres euforii związanej z wejściem Polski do strefy Schengen minął. Podobnie zapomniane już zostały wszelkie ograniczenia i okresy przejściowe na podejmowanie przez Polaków pracy w innych krajach UE.

Pamiętam czasy, kiedy trzeba byto oddać dowód, żeby paszport dostać, w tej chwili planuje wyjazd, dla mnie jest to taka naprawdę wolność (SZ/SZ/11).

Dla mnie osobiście to jest jakaś taka, no, otwartość. To, że jakoś tak bez problemu cztowiek może sięporuszać w granicach tej Unii. [...] to, to jest taka otwartość (SZ/SZ/12).

Patrzą szerzej, integracja [kojarzy mi się - M.N.] to gtównie z możliwością nieskrępowanych podróży po Europie, poznawania innych ludzi, państw, z większymi ogólnie możliwościami dziatania w wielu dziedzinach (NR/L/04).

Unia kojarzy mi się z możliwościami podróżowania bez granic, kontroli, z tym, że ten przejazd jest dużo szybszy niż kiedyś, jak tu jeździtem do teściów (S/SZ/06).

Tak więc zdarzające się sporadycznie w wypowiedziach powyżej, a dość patetycznie dzisiaj brzmiące hasła o swobodach, jedności i otwartości, które przecież odnoszą się do historycznych podstaw i początków procesu integracyjnego Europy i do szansy, jaką dało w związku z tym wejście Polski do UE, zastępowane są coraz częściej refleksją odnośnie do powodów i konsekwencji wyjazdu młodych Polaków z kraju i brakiem perspektyw w ojczyźnie. Innymi słowy, dla większości pytanych wspominane wolności są czymś oczywistym i danym raz na zawsze, a respondenci zaczynają już wyraźnie dostrzegać zagrożenia związane z tak dużą skalą emigracji zarobkowej, podziałem rodzin, a wręcz wyludnieniem się niektórych wiosek. Poza brakiem pracy jest to chyba najczęściej wymieniane przez odpowiadających zagrożenie dla przyszłości państwa rozpatrywane już w kategoriach narodowej tragedii.

Moja córka siedzi już trzeci rok $w$ Anglii. Pewnie bez Unii by tam nie wyjechata albo wyjechataby gdzieś indziej. Ludzie stąd dużo wyjeżdzali... (L/G/07).

Wyjeżḋaja, nie ma pracy, nie ma. Ci mtodsi, co ich nic nie trzyma, to na dtużej. W tej chwili żona jest w Belgii, truskawki rwie (S/BD/01).

Nie ma perspektyw u nas, to jadą i szukaja roboty, nie ma się co temu dziwić. Kiedy ja bytem w takim wieku jak mtodzi dzis, to siępracowato, robota byta dla każdego prawie, nie to, co teraz. Nie trzeba byto wyjeżdżać, żeby pracować (Z/Z/07).

Tak, nawet bardzo jest wysoka [emigracja - M.N.]. W ogóle jest to taki trend bardziej ogólnopolski. Mądra mtodzież, wyksztatcona emigruje do Niemiec i Irlandii i jest to tragedia (NS/S/03).

Podsumowując tę część tekstu, stwierdzić należy, że członkostwo Polski w Unii Europejskiej cieszy się nadal ogromnym poparciem w polskim społeczeństwie, co wynika z często podkreślanego i widocznego w małych ojczyznach skoku cywilizacyjnego, jaki dokonał się w ostatnich latach. Skala inwestycji infrastrukturalnych jest tak duża, że Polacy w Unii Europejskiej dostrzegają przede wszystkim donatora oferującego bezzwrotną pomoc. Część respondentów widzi jednak w UE instytucję o charakterze bankowym, której kiedyś trzeba będzie tę pomoc oddać z procentami. 
Wynika z tego, iż dla wielu pytanych obecność Polski w UE jest akceptowalna i cieszy się ich poparciem tylko w takiej sytuacji, kiedy Polska więcej od UE otrzymuje, niż do niej wpłaca. Przy czym mowa jest tu głównie o pieniądzach, a nie o wartościach czy kulturze. Jest to dowód na to, że w perspektywie lat poparcie dla obecności Polski w UE będzie maleć wraz z rosnącym PKB, co docelowo doprowadzić może do sytuacji, iż staniemy się jako kraj płatnikiem netto do budżetu UE. Tezę tę uprawdopodabnia fakt, iż znacznie rzadziej respondenci odnoszą się w wypowiedziach do innych korzyści związanych z członkostwem w UE (cztery swobody wspólnego rynku, swobody obywatelskie).

\section{EUROENTUZJAZM VS. EUROSCEPTYCYZM}

Biorąc pod uwagę opisywany powyżej stopień poparcia dla uczestnictwa Polski w UE, trudno w tym miejscu nie wspomnieć o jednocześnie bardzo negatywnym nastawieniu do przyjęcia wspólnej waluty EURO przez Polskę ${ }^{11}$. Jeśli poruszamy tę kwestię w tym miejscu, to dlatego, iż widoczny w wielu wywiadach euroentuzjazm, podparty najwyraźniej miliardami EURO pochodzącymi z funduszy pomocowych, stoi ewidentnie w sprzeczności ze stosunkiem Polaków do wspólnej europejskiej waluty. Niemal każdy respondent wypowiadał się bądź to w ogóle przeciwko jej wprowadzeniu (gorzej wykształceni, gorzej sytuowani), bądź też za możliwie jak najpóźniejszym wejściem naszego kraju do strefy EURO (lepiej wykształceni, lepiej sytuowani). Tak więc zaobserwować możemy swoistego rodzaju ambiwalentną postawę Polaków w tym względzie w postaci zderzenia wykazanego powyżej euroentuzjazmu z EUROsceptycyzmem, przy czym oczywiście minimalna jest wiedza o tym, że Polska musi wspólną walutę przyjąć i zostało to już zdecydowane w tzw. traktacie akcesyjnym ${ }^{12}$.

Nie, nie jest bardzo ważna [waluta EURO - M.N.], generalnie w referendum zagtosowatabym na nie, bo jak przeliczyliby nam pensje, to wysztoby to strasznie żatośnie. Poza tym bojęsie, że w trakcie przyjmowania EURO straszniepodskoczytyby ceny żywności i ustug (NS/NS/04).

[...] E... ja się boje [...] tak, tylko dobrze, wie Pan, że ja jadę i mam EURO, tylko jak moja emerytura będzie przeliczona, to wie Pan... Ja tego nie widze wesoto (NR/J/01).

Jestem przeciwny EURO. Po co mi to? [...] Niech mi Pan powie, że ceny nie pójda. w góre, jak przyjmiemy EURO. Pójdą. To każdy wie. Wedtug mnie na choleręnam, to i na cholere potrzebne to innym (L/G/04).

11 Na ten temat zob. również artyku1: M. Góra, „Nie taka Unia straszna, jak ja maluja”? Stan integracji europejskiej i przysztość Unii Europejskiej w oczach Polaków w niniejszej publikacji.

12 Zgodnie z art. 4 tegoż traktatu Polska (i inne kraje przystępujące do UE w 2004 r.) objęta została jedynie derogacją w związku z obowiązkiem przyjęcia wspólnej waluty EURO. Zob.: Traktat [...] dotyczacy przystapienia Republiki Czeskiej, Republiki Estońskiej, Republiki Cypryjskiej, Republiki Eotewskiej, Republiki Litewskiej, Republiki Wegierskiej, Republiki Malty, Rzeczypospolitej Polskiej, Republiki Stowenii i Republiki Stowackiej do Unii Europejskiej, podpisany w Atenach w dniu 16 kwietnia 2003 r., Dz.U. 2004, nr 90, poz. 864 . 
Myśle, że bardziej negatywnie bym tu odpowiedziata. Nie podoba mi się ten pomyst, $z$ tego, co wiem, to nie jest dobry pomyst (Z/Z/04).

Przypadki pełnego poparcia dla przyjęcia przez Polskę wspólnej waluty były jednostkowe i powiązane raczej z codziennym trybem życia (podróże, emigracja) lub wykonywaną pracą zawodową. W przeciwieństwie do cytowanych wyżej głosów przeciwnych, które nieprzypadkowo są bardzo krótkie i niepogłębione, wypowiedzi za przyjęciem wspólnej waluty charakteryzowały się zawsze dłuższym wywodem świadczącym przynajmniej o jakiejkolwiek refleksji związanej z posiadaną wiedzą oraz systematycznym dostępem do różnych źródeł informacji.

Powiem wprost, żeby nie ta Unia, to by tu u nas psy [wulg.] szczekaty. Nie bytoby żadnego rozwoju. Powiem Panu więcej, Ja strasznie żatuje, że od razu nie weszliśmy do strefy EURO. No może nie od razu, ale tak 2006-2007 to bytoby dobrze. [...]. Bytoby ze wszystkim dużo tatwiej. To już nawet nie chodzi o podróże, ale niech Pan zobaczy, jak te kredyty w tym kryzysie Polaków przygniotty. Gdybyśmy mieli EURO, to ludzie by nie odczuli tak kryzysu na rynku kredytowym. Ja mam znajoma Stowaczkę, która sptaca kredyt, to jak EURO w Polsce poszto w górę, i ten kryzys się zacząt, to byta przeszczęśliwa, że nie zostali przy koronie. Choć oczywiśsie z drugiej strony narzeka, że ceny poszty w gorę. Problem raczej jednak polega na tym, że trzeba sobie zadać pytanie, czy ceny nie posztyby w górę i bez tego (SZ/SZ/16).

No powiem tak. [...] może nie teraz, ale generalnie uważam, że powinna być wspólna waluta. Chociażby rozliczenia, zmienne kursy, uprościtby się eksport. Gtupia zmiana stopy procentowej NBP o ćwierć punktu już powoduje ogromne ktopoty, bo jedna waluta się ostabia, a inna wzmacnia. To naprawdę wiele rzeczy by uprościto. Poza tym jest to waluta, z która się liczy caty świat. To oczywiście nie reguta, bo Brytyjczycy czy Szwajcarzy nie maja EURO, a też się z nimi licza. To jednak nie jest nasz przypadek. [...] Myśle, że EURO trzeba przyjać. Ten kryzys wiele rzeczy naprostowat i nauczyt. Jak teraz sięprzyjmie jednolita. politykę i to zacznie dziatać, to w perspektywie czasu EURO powinniśmy przyjąć. Problem polega na tym, że ludzie nie maja świadomości że to EURO przyjać musimy, że to już jest zdecydowane. Pytanie brzmi tylko „kiedy?”(SZ/SZ/15)

Konkludując kwestię tak negatywnego stosunku Polaków do przyjęcia wspólnej waluty, wskazać trzeba nie tylko nikłą wiedzę o mechanizmach wspólnego rynku Unii Europejskiej (dla przykładu żaden przedsiębiorca, z którymi przeprowadzano rozmowy, nie wiedział o możliwości startu w przetargach publicznych organizowanych w innych państwach UE - To można? Nie wiedziatem. To dobrze, spróbujemy, bo ludzie o tym nie wiedzq (SZ/€/05)), ale przede wszystkim skandalicznie wręcz niską ogólną wiedzę ekonomiczną Polaków. Tylko nieliczne wypowiedzi wskazywały na posiadanie minimalnych chociażby kompetencji w tym zakresie, a dopytywani respondenci w zasadzie nigdy nie potrafili uzasadnić swych poglądów.

Generalnie rzecz biorąc, zasób wiedzy o wprowadzeniu EURO w naszym kraju sprowadza się do twierdzenia graniczącego z pewnością, iż pensje (oraz renty, emerytury i inne dochody) zostaną przeliczone w stosunku ok. jeden do czterech, natomiast ceny wszystkich artykułów i usług w stosunku jeden do jeden bądź w najlepszym razie jeden do dwóch. Dla wszystkich respondentów oznacza to więc bez wątpienia spadek 
dochodów połączony ze wzrostem cen, tym bardziej że stopień zaufania do państwa i jego instytucji (o czym poniżej) oraz do właścicieli sklepów i sieci handlowych jest bardzo niski. Często w tym kontekście pojawia się określenie o kolejnym „kręceniu lodów" i nieuczciwych praktykach handlowych. Nie bez znaczenia dla takich sceptycznych wobec EURO postaw jest oczywiście kryzys finansowy i kłopoty gospodarcze niektórych krajów europejskich, które wspólną walutę przyjęły, jak i często powtarzane w mediach informacje, że (słaba) złotówka uratowała Polskę przed kryzysem ${ }^{13}$.

Ja osobiście uważam, że nie wprowadzać. Przywiąana jestem do naszego polskiego ztotego. Ja pamiętam, że mojej mamy sąsiadka, która mieszka teraz $w$ Niemczech, tak strasznie się cieszyta, jak to EURO wprowadzali, to potem mówita, że jak dawniej chleb np. kosztowat marke, to teraz kosztuje 1 EURO. [...] Nie wiem. Przeciez jaki by nie byt przelicznik, to ceny na pewno wzrosna. Przecież nikt nie będzie do tego doktadat, a każdy będzie chciat zarobić. Myśle, że jakby Pan przeszedt przez cata wioskę, to absolutnie wszyscy byliby na "nie” (SZ/E/02).

EURO jest dla bogatych. Prosze Pana, dzisiaj gdyby byt średnio tysiac ztotych emerytury, to to jest 220 EURO. Prosze Pana, bo ceny zrobia podobne. I co? Optać, wyżyj i jedź gdzieś. No chyba, żeby zrobili jeden do jeden, ale to wzyciu nie będzie. A to jeden do jeden to obiema rękami siępodpisuje, no! Prosze Pana, ci, co maja kupę kasy, to oni wydola, ci przedsiębiorcy, co sprzedaja na Zachód, to nie chca. Nie chca, bo to stuchatem, ja zreszta. wszystkie wiadomości stucham. To by byto dobre to EURO, tylko gdyby nasze pensje byty wyższe. Pensje, emerytury, bo nie można się sugerować tym, że jak ktoś ma 5 tysięcy ztotych, to dla niego robi się to EURO. Bo sa jeszcze tacy, co biora po 800, moja mama bierze 900 ztotych emerytury (SZ/N/01).

Nie wydaje mi się, zeby to musiato nastapić teraz, sa obawy przed EURO, obawy przed podwyżka cen przede wszystkim. Nie jesteśmy na to jeszcze gotowi, może w jakiejśperspektywie, ale nie teraz. Sam pomyst chyba jest nie najgorszy, wygodne bytoby postugiwać sie tym samym pieniądzem w catej Europie czy Unii. Można to też wszędzie wymienić, więc to taki jakby „europejski dolar”. Jak mówię, największe obawy to jeżeli chodzi o te ceny, nie wiadomo, jakby to mogto wygladać (S/BD/03).

$\mathrm{Z}$ powyższych wypowiedzi wynika niezbicie, jakie wyzwania stoją przed elitami politycznym kraju w związku z przyjęciem EURO i przekonaniem do tego polskiego społeczeństwa. Kompletny brak rzetelnych danych i jakiejkolwiek polityki informacyjnej ze strony instytucji państwowych pogłębia negatywny stosunek Polaków do EURO. Mimo wszystko jednak pamiętać trzeba, że pojawiają się także wśród respondentów wypowiedzi wskazujące na konieczność bądź to edukacji, bądź też zorganizowania stałego systemu informacji w tym względzie. Opinie te oczywiście nie biorą zupełnie pod uwagę takich czynników jak konieczność zmian w Konstytucji RP i rozważań, czy politycy będą w ogóle chcieli wypełnić zobowiązania wynikające z przystąpienia Polski do UE.

13 Należy zauważyć, że wszystkie wywiady przeprowadzone zostały jeszcze przed agresją Federacji Rosyjskiej na Ukrainę. Od tego czasu odpowiedzi o przyjęcie EURO przez Polskę mogłyby być w mniejszym stopniu determinowane względami ekonomicznymi, a na poglądy części respondentów mógłby wpływać obecnie aspekt polityczny silniejszego powiązania z EUROstrefą i poczucia większego bezpieczeństwa (przykład Litwy). 
Powiem szczerze, że nie znam żadnych szczegótowych opracowań, wiem tylko tyle, co podaja media, a to jest chaotyczny przekaz. Generalnie ludzie, i ja podobnie, reaguja raczej sceptycznie. Raczej można się obawiać. Fajnie, bo zniknie problem przewalutowań, ale z kolei jeśli ceny maja poszybować w górę, to może być trochę problem. To trzeba by Polakom jakośn naprawdę doktadnie wyttumaczyć (NR/L/04).

[...] Teraz, Panie, to ja jestem skotowany. Ja nie jestem ekonomista i mnie ekonomii nikt nie uczyt. Ja skończytem tylko technikum kolejowe. Na poczatku bytem „za”. Teraz troche jestem sceptyczny, ale generalnie uważam, że powinniśmy EURO przyjąc. Przecież tam sa już kraje i biedniejsze od nas i gorzej zarzadzane, więc dlaczego nie? Przecież w wielu krajach, które mają EURO, bieda jest jeszcze większa niż u nas. Na przyktad taka Portugalia. Przecież wszystkie te kraje, jak Irlandia, Portugalia, Hiszpania, już o Grecji nie mówiąc, to one stanęty na nogi tylko dzięki Unii Europejskiej. Skoro już więc jesteśmy w tej unijnej „bandzie”, to ze wszystkimi tego konsekwencjami (SZ/SZ/16).

\section{ZADOWOLENIE Z POZIOMU POZYSKANIA I WYKORZYSTANIA PRZEZ SAMORZĄDY FUNDUSZY EUROPEJSKICH}

Trzeba przyznać, iż zapóźnienie cywilizacyjne i infrastrukturalne Polski po 1989 r. było tak duże, iż z przeprowadzonych wywiadów wynika, że mieszkańcy są zadowoleni niemal z każdej inwestycji, którą udało się wykonać na terenie ich gminy. Nie oznacza to bynajmniej, że wśród mieszkańców panuje zgodność co do celowości, zakresu i jakości niektórych inwestycji, zwłaszcza iż wbrew pozorom zdają sobie sprawę z tego, że mają one często charakter permanentnej kampanii wyborczej danego wójta czy burmistrza. Z cytowanych poniżej wypowiedzi wynika jednak, że głosy krytyczne bywają najczęściej wewnętrznie sprzeczne. Czasami więc mieszkańcy uważają, że trzeba było wykonać inwestycje taniej, ale zrobić dzięki temu więcej; innym razem zaś zwracają uwagę, że inwestycja była źle przygotowana, cięto koszty i w efekcie wykonane prace są nietrwałe.

Co do tych twardych inwestycji, to generalnie nie mam zastrzeżen więszych, ewentualnie moge przyczepić się do wykonawstwa [...] nie mogęprzeżyć na przyktad, jak schody zrobione w ramach renowacji czegoś tam krusza się po 6 miesiacach użytkowania (Z/Z/10).

[...] wszystko, co zobaczymy, to jest wykonane na środkach unijnych. Jakieś rewitalizacje niedawno przeprowadzone [...], to wszystko w dużej części opiera się na środkach unijnych. [...] One sa jak najbardziej potrzebne. Wszystko się kieruje tym, co jest najtańsze, to jest główne kryterium, i kończy się, jak się kończy. I efekt jest czasami różny, trochę dalszy od zamierzonego $(\mathrm{Z} / \mathrm{Z} / 03)$.

Ja mogępowiedzieć z mojej strony. Oczywiście bywa, że sa osoby, które mówią, że winny sposób zrobić, taniej. Natomiast widzę z drugiej strony, że gdzieś w tych miastach, gdzie pieniądze docieraty wcześniej, wtaśnie dziśśsiaga się tą kostkę betonowa i robi się granitowa. Więc jest pytanie, dlaczego od razu nie robić porzadnie, w jakimś wyższym standardzie? Często przez to, że byto zrobione taniej, to dziśsię poprawia (NR/J/03).

Bo co wybory, co cztery lata, burmistrz robi po 200 metrów. Maja być wybory, to droge trochę porównają i jest, żeby można byto do pól dojechać. Tyle się dzieje. [...] Będą wybory, 
to zrobiaznów 200 metrów chodnika. Chociaż [dzięki temu - M.N.] ja mam już chodnik koto domu [śmiech] (Z/K/06).

Tego typu głosy dają niestety urzędnikom i funkcyjnym samorządowym powód do usprawiedliwiania się, że cokolwiek nie zostałoby zrobione, to i tak spotka się z krytyką części mieszkańców gminy (Jeszcze się taki nie urodzit, co by wszystkim dogodzit (SZ/E/02)). W takich przypadkach lokalni decydenci zwykli narzekać, że mieszkańcy nie chcą być partnerem i trudno jest z nimi prowadzić jakikolwiek dialog. $\mathrm{O}$ tym problemie będzie jeszcze mowa poniżej, ponieważ z przeprowadzonych rozmów wynika, że podstawowym mankamentem polskiego modelu samorządności i jedną z największych porażek procesu decentralizacji kraju jest oderwanie lokalnych elit od wyborców i brak wypracowanego modelu konsultacji społecznych.

Widoczne na poziomie gminy i powiatu inwestycje powstałe w wyniku dofinansowania z funduszy UE z założenia powinny przysparzać ogromnej popularności politykom lokalnym. Większość z nich mogła w tym przypadku zdyskontować fakt, iż przyszło im sprawować funkcje w okresie pierwszego pełnego uczestnictwa Polski w budżecie UE (2007-2013). W zdecydowanej większości respondenci potrafili docenić wysiłki władz lokalnych w tym kierunku, a działania samorządów w ostatnich latach rzeczywiście były skierowane w pierwszym rzędzie na jak największe wykorzystanie możliwości, jakie dało zarówno członkostwo Polski w UE, jak i decentralizacja kraju. W tym kontekście lokalne elity mogły trafić na dwie potencjalne przeszkody w realizacji zamierzeń.

\section{ZADŁUŻENIE SAMORZĄDÓW}

Pierwsza z nich dotyczy problemu znalezienia w budżetach swych gmin środków na pokrycie tzw. udziału własnego w inwestycji współfinansowanej z funduszy UE. Efektem tych działań jest ogromne zadłużenie samorządów w naszym kraju, o którym wie niemal każdy przepytywany respondent.

Większość myśli jednak, że lepiej sięzadtużyć, żeby coś zrobić. Bo z czasem uda się z tego dtugu wyjść, a to już zostanie, jest. Zostanie dla następnych. Nasza gmina jest bardzo zadtużona. Ale miejmy nadzieje, że jakoś tam powoli wyjdziemy z tego (Z/S/02).

Jesteśmy chyba najbardziej zadtużona gmina $w$ Polsce, $i$ to jest straszne, ale powiem tak. Wole, żeby te pieniądze byty wykorzystane i żebyśmy mieli wodociagi, żebyśmy mieli deptak, przejścia, tawki, chodniki, podjazdy itd., aniżeli te pieniadze bytyby w banku. Nie wiem, ja się tam cieszę, że to w ogóle jeszcze wszystko nie padto przez to cate zadtużenie (SZ/SZ/19).

$W$ gminie myślé, że tak, na tyle, na ile pozwalaja na to fundusze, bo trzeba przecież pamiętać o wktadzie wtasnym, bez tego ani rusz. A pod tym względem środki sa przecież ograniczone, nie można się zadtużać $w$ nieskończoność, choć chciatoby się zrobić więcej, jeszcze lepiej (NR/J/04).

$\mathrm{Z}$ analizy wywiadów pod tym kątem wynika jednoznacznie, że respondenci generalnie zgadzają się na zadłużanie swych samorządów, jeśli wymaga tego interes społeczny, 
dobro gminy czy też nawet jej reputacja (wobec konfrontacji osiągnięć z sąsiednimi gminami). Dość powszechną opinią jest często przytaczane zdanie iż dtugi się kiedyś przecież sptaci, a inwestycja pozostanie na lata. Rzadko kto jednak zdaje sobie sprawę z zależności między długiem gminy a podatkami lokalnymi, że dług gminy to również dług jej mieszkańców oraz że konsekwencją tego zadłużenia może być wzrost obciążeń nakładanych przez gminę na mieszkańców. Postawa ta jednak wpisuje się we wspominany już wcześniej problem niskiej wiedzy ekonomicznej Polaków. Warto zwrócić uwagę, że społeczności lokalne akceptują nie tylko zadłużanie się na tzw. „inwestycje twarde" (drogi, kanalizacje, wodociągi itp.), ale również wydatki na kulturę oraz kulturę fizyczną i edukację (festiwale, boiska, biblioteki, place zabaw) oraz - co zaskakujące - na estetykę otoczenia.

\section{KOMUNIKACJA OBYWATEL-URZĄD I KONSULTACJE SPOŁECZNE}

Jak wspomniano powyżej, drugą poważną przeszkodą w realizacji zamierzeń związanych $\mathrm{z}$ sięganiem po zewnętrzne finansowanie są ewentualne zarzuty mieszkańców (i wyborców jednocześnie) odnośnie do trafności inwestycji na poziomie lokalnym, co sprowadza się do ogromnych problemów (wręcz braku) w komunikacji na linii władze samorządowe-mieszkańcy. Biorąc pod uwagę przytoczony wcześniej proces decentralizacji państwa, za pozytywny należy jednak uznać trend, jaki coraz częściej pojawia się w wypowiedziach respondentów; generalnie zadowoleni z poczynionych przez władze lokalne inwestycji i starań o fundusze, zwracają coraz częściej uwagę, że decyzje inwestycyjne były podejmowane w sposób dla nich niezrozumiały, poza nimi i bez żadnych konsultacji z mieszkańcami gminy.

Jak cośsię dzieje, to dochodza te informacje przezpania sottys przede wszystkim. Jak coś się dzieje, to to jest gtówne źródto informacji, ale nie wiem, jak to wyglada winnych miejscowościach, trudno mi się do tego odnieść, bo nie mam takich informacji. Ale z rozmowami o np. inwestycjach to się raczej nie spotkatam (Z/S/02).

Tak, oczywiście, niestety niewykorzystywanym. Ludzie na konsultacje nie chodza. Nie chce im się czy się boja. To jest mate środowisko i boja się napiętnowania, boją się o pracę. I jak tak nie chodza, to wtadza nie ma powodu, żeby zwotywać takie posiedzenia, no i umiera to trochę śmiercia naturalna (L/G/08).

[Konsultacje?] ja o niczym takim nie styszatem. Nasza wieś to tu jest catkiem na uboczu, zmarginalizowana. Tu się po prostu nic nie dzieje, nie ma żadnych rozmów. Jak się wybory zblizaja, to tylko cośobiecują i obiecują, i nic z tego $(\mathrm{Z} / \mathrm{K} / 06)$.

Ja w ogóle chciatbym mieć szanse na wypowiedzenie się w ważnych dla regionu kwestiach. Wtadza lokalna, $i$ to nieważe, czy gmina, czy miasto, jest niezwykle arogancka i nie chce takich rzeczy organizować. To znaczy sa spotkania z sottysem, i czasami dyskutujemy na temat rozdysponowania pewnych środków. [...] Dialog jest albo bardzo ograniczony, albo nieistniejacy (L/G/06).

Rzeczywiście, trzeba przyznać, że jeśli chodzi o działalność władz samorządowych, kwestia konsultacji społecznych, przybliżania mieszkańcom mechanizmów i procedur 
ich działania oraz przekazania im realnego wpływu na podejmowanie decyzji wyrasta właściwie na podstawowy problem polskiej demokracji lokalnej. Często więc w rozmowach na temat działalności władz lokalnych pojawiają się bardzo ostre sformułowania, jak: arogancja, poczucie nieomylności, własna wizja, stawianie sobie pomników, znajomości, a nawet nazywanie gminy wprost od nazwiska ich włodarzy ${ }^{14}$.

[Konsultacje?] Nie spotkatem się z tym, a jestem na miejscu, to bym wiedziat, ktośby mówit czy powiedziat. Ale to, Panie, jedna banda jest i uważają, że wszystko wiedza, to co mają konsultować? Przecież oni sa najmądrzejsi [śmiech]. To jest doktadnie jak za komuny: byt sekretarz ze świta, a ludzi to oni mieli $w$ [wulg.], sami podejmowali decyzje i teraz jest, powiem Panu, tak samo. Nic się $w$ tym względzie nie zmienito, nic (Z/Z/06).

Osobnym tematem często poruszanym przez respondentów podczas rozmów o działalności władz samorządowych i urzędów jest znany powszechnie problem nepotyzmu (kolesiostwo, lokalne kliki, klientelizm itp.), postrzegany już często w kategoriach najgorszej choroby toczącej Polskę samorządową. Nepotyzm jest piętnowany obecnie szczególnie, ponieważ w zgodnej opinii respondentów nie ma już ani charakteru czysto rodzinnego, ani nawet kolorów partyjnych, liczy się tylko wspólny interes i potencjalne korzyści, jakie z tego „lokalnego układu” można wyciągnąć. Na najniższych poziomach samorządu terytorialnego najczęściej w tym kontekście wymieniane jest niestety Polskie Stronnictwo Ludowe, które według respondentów - jak żadna inna partia - potrafi stworzyć mityczny „lokalny układ” i zyskać poparcie społeczne poprzez rozdawnictwo etatów w różnego rodzaju instytucjach państwowych, obsługujących głównie rolników i społeczności lokalne (Agencja Restrukturyzacji i Modernizacji Rolnictwa, Lasy Państwowe, Powiatowe Urzędy Pracy itp.). PSL jest również wymieniane najczęściej w kontekście działalności lokalnej Ochotniczych Straży Pożarnych jako politycznego zaplecza partii. Przyznać trzeba, że z perspektywy wyniku PSL w ostatnich wyborach samorządowych z jesieni 2014 r. wygłaszane opinie wydają się mieć pewne podstawy.

No jest jeszcze jeden problem, bo żona tu mówita o nepotyzmie. Ja myśle, że znacznie gorsze jest to, że zatrudnia siępo linii partyjnej i ideologicznej. Panie kochany, PSL wznosi sięna wyżyny tego procederu, a PiS wcale nie jest gorszy. No Platforma, to tylko tam, gdzie jeszcze wolne miejsce zostato [śmiech] [...] Tak że to ma teraz taki podwójny wymiar, nepotyzm rodzinny i koleżeński plus nepotyzm partyjny. Czasami to już nawet nie ma znaczenia, kto do jakiej partii należy, byle byli znajomi (SZ/SZ/16).

Rządzi klika Skiby i osób z nim powiązanych. A wie Pan, kto tak naprawdę rzadzi? Nie żadne PO czy PiS, tylko PSL. A nawet więcej, jego zbrojne ramię. A wie Pan, jakie? Ochotnicze Straże Pożarne. Ostatnio jak byto trzy tygodnie przed wyborami, to przywieźli skrzynki wódki do remizy i urzadzili spotkanie, bo ludzie to wiedza, na kogo gtosować.

14 Chodzi o często powtarzane zwłaszcza w gminie Zwierzyniec pogardliwe określenie „Skiboland” jako nazwy dla całej gminy: Jak powiedziatbym, to jest Skiboland, to co się tu wyprawia. Kto ma korzyść z tego? Ten Skiba to [wulg.] jest. Sam on korzysta i wszyscy co z nim trzymaja (Z/G/01). Często też w Zwierzyńcu używane jest słowo „Skibończyk” na określenie nazwy największej inwestycji (tzw. Zwierzyńczyk) - od nazwiska burmistrza Jana Skiby, który piastuje swój urząd nieprzerwanie od 1990 r. $(\mathrm{Z} / \mathrm{Z} / 12)$. 
I tak ich przekonują. I znów wybrali tych samych, nie pamiętam, która już kadencję on rzadzi, jeszcze byt przecież naczelnikiem gminy (Z/G/01).

Ja wiem, mój kolega w 2000 roku zapisat się do PSL razem z żona, bo potrzebowat dostać prace u wójta, który byt z PSL-u, to faktycznie [...]. No i dostata ona tę prace, to tak, to taki znany mi przyktad osobiście, to pamiętam, że ludzie musieli się do tego PSL-u zapisywać, żeby w tych urzędach gminnych pracować, to tak (NR/B/05).

\section{ZADOWOLENIE Z PRACY URZĘDÓW I URZĘDNIKÓW}

Zupełnie nowym wątkiem, który pojawił się podczas przeprowadzanych wywiadów, jest powiązanie Unii Europejskiej z pracą władz samorządowych i jej krytyka w tym kontekście. I w tym przypadku wypowiedzi przepytywanych respondentów nie podważają samej potrzeby i idei integracji europejskiej oraz członkostwa naszego kraju w jej strukturach. Ostrze tej krytyki nakierowane jest wyraźnie na sposób działania urzędów i urzędników wszystkich szczebli samorządu terytorialnego i najczęściej sprowadza się - co należy bardzo mocno podkreślić - do przerostu administracji, niepotrzebnych procedur, biurokratyzacji i obaw urzędników przed samodzielnym podejmowaniem decyzji ${ }^{15}$. W efekcie spotykamy tutaj małą liczbę odpowiedzi krytycznych o charakterze bardzo ogólnym, związanym z tym, że na urzędników i urzędy narzekało się zawsze.

No na plus, nie uwsteczniamy się tak, jak to byto wcześniej. Jednak idziemy caty czas do przodu i rozwijamy się. Widać te drogi i generalnie infrastrukturę [...]. Wydaje mi się, że cata branza budowlana przez te projekty nieco zyskata. Generalnie wszystko na plus. Na minus? Biurokracja, to na pewno, zostaliśmy zalani papierkami i czasami bezsensownymi regulacjami (L/G/03).

Unia kojarzy mi się z tworem, który w zamierzeniu początkowo, w obliczu zagrożenia przed ZSRR byt dobra próba stworzenia przeciwwagi dla bloku wschodniego. Jednak z czasem UE zaczyna mi się kojarzyć z jakimśtakim tworem biurokratycznym (L/G/06).

Zdecydowana większość respondentów mających częsty kontakt z urzędami udzielała odpowiedzi bardzo szczegółowo wskazujących obszary największych problemów i znakomicie diagnozujących istotę działania współczesnej administracji publicznej. Te wypowiedzi jednak nie wiążą się w żaden sposób bezpośrednio z działalnością Unii Europejskiej i przynależnością Polski do niej.

Pomagaja [urzędnicy - M.N.] i ile razy bym tam nie poszedt, to zawsze widze życzliwość $i$ otwartość. Ale żeby byto jasne, [...] generalnie wszyscy się czegoś boja, boja się podejmować decyzje, a wiele niepotrzebnych papierków jest robionych „na wszelki wypadek", żeby wtasna [wulg.] chronić (SZ/七/05).

Żeby byto jasne, ja sobie zdaje sprawę, że oni [urzędnicy - M.N.] nie wszystko mogq $i$ wiem - a to już kolejny ważny problem - że wszelkie procedury sa tak gtupie i nieprzemyślane, że my sobie sami często roboty dodajemy, a i administracja przy tym

15 Również ten problem dostrzegają sami urzędnicy, skarżąc się na nadmiar wykonywanej i często dublowanej pracy. 
nie tylko się rozrasta, ale i jest coraz droższa. Na wszystko musi być gtupi papierek. Brak po prostu zwyktego zdrowego rozsadku w tym wszystkim i każdy boi się podjąć jakąkolwiek decyzję. To, co sie dzieje na poziomie lokalnym, to jest po prostu niewyobrażalne i wszyscy na to narzekaja. Nic się nie poprawia (SZ/SZ/16).

[...] jedno Panu powiem - my, Polacy, to sobie sami komplikujemy życie, a potem $z$ tego bezrobocie się dzieje. Fakt jest, że może cośtam z tej Uniipewnie przejęliśmy tej takiej urzędniczej nowomowy, ale to, co siejuż tu dzieje, to już jest przesada. Potem się dziwia, że przedsiębiorstwa upadaja... A wie Pan, co jest najgorsze? Każdy urzędnik niby to chce pomóc - nie moge powiedzieć, bo u nas w gminie urzędnicy pomocni sa. Jest tylko jeden problem. Doprowadziliśmy do sytuacji, że każdy się boi samodzielnie podjąćjakąkolwiek decyzję. Każdy chce mieć na wszystko podktadkę, żeby swoja [wulg.] chronić. Po co to wszystko, po co tyle przepisów? Życie, wie Pan, ma swoją logikę i jak przepis jest gtupi, to i tak go obejdą, a papieru niepotrzebnie tyle się zużywa. Tak się to rozgadatam i narzekam, ale to czysta prawda i niech Pan to zapisze gdzieś tam, bo może to dojdzie do tych gtupich tbów [...].Ja mówię o polskich urzędnikach, o polskich procedurach i o naszej polskiej gtupocie. Nie mieszajmy w to Unii, bo tak mi się coś wydaje, że ona nie ma nic do tego (SZ/SZ/14).

To tylko najłagodniejsze, ale jednocześnie dobitne przykłady bardzo zdecydowanych wypowiedzi, przy czym regułą jest, że mieszkańcy narzekają na działalność urzędów (zarówno administracji rządowej, jak i samorządowej), z którymi mają do czynienia najczęściej. Na uwagę zwraca fakt, iż respondenci pytani byli o pracę urzędów w kontekście członkostwa Polski w UE, tymczasem w zdecydowanej większości odpowiedzi Unia Europejska wcale nie była kojarzona z przerostem administracji, a raczej trudnym językiem, swoistego rodzaju eurokratyczną nowomową.

Nie podobaja się ludziom nie tyle unijne przepisy, tylko interpretacja naszego przetożenia tych przepisów. To tak. [...] Sama Unia jednak, to ja tam nie mam żadnych nieprzyjemności z przepisów unijnych, a przynajmniej nic nie czuje (SZ/Ł/02).

Tak, tak. Tym bardziej że ja teraz widzé, że to ma cośz propaganda wspólnego. Bo ja parę wypetnitam wniosków o fundusze europejskie $i$ zauważytam, że tam jest swoista nowomowa taka europejska, raczej unijna. Jest taka nowomowa. Nie ma remontu, jest modernizacja, nie ma jakiegoś usprawnienia, jest innowacja, i nawet na takim kursie, na którym uczono nas wypetniania tych formularzy, uczono nas, żeby stosować takie stowa klucze. I to mi się też nie podoba (NR/B/04).

Tylko żeby nie mieć klapków [sic] na oczach i żeby rozumieć to, co tam napisane [np. w procedurach przetargowych - M.N.], to już inna spawa. Przecież wie Pan, że w tych różnych dokumentach to takie sformutowania używaja, że normalny cztowiek nie jest $w$ stanie tego pojać. Ja tu nieraz w barze styszatam, bo do mnie tu na obiady budowlańcy przychodza, że na przyktad te dokumenty różne, co to je trzeba przygotować, to takie nazewnictwo maja, że nie wiadomo, o co chodzi. Efekt jest taki, że potem ludzie mówia, $\dot{z} e$ to specjalnie tak jest, żeby startujący do przetargów sie przestraszyli, bo przetarg ma wygrać ten a ten. Tu przyznam, że się czasami sama nad tym zastanawiam, czy to racji w tym nie ma. [...] Ooo, Panie kochany. To nie to, że on [język] jest trudny, bo każde stówko z osobna to cztowiek może znać. Tyle tylko, że jak się to ztoży w catość do kupy, to nie wiadomo, o co chodzi (SZ/SZ/14). 
Oskarżenia o nadmiar biurokracji były natomiast wyraźnie skierowane pod adresem polskich urzędników i polskich procedur. Sami urzędnicy natomiast bronią się, narzekając na nadmiar przepisów, ich częste zmiany, niepotrzebnie powielaną sprawozdawczość i dublowanie się informacji w różnych dokumentach.

[...] oczywiście można narzekać na urzędy, że to one utrudniaja, bo każa wypetniaćpapierki. Trzeba pamiętać o tym, że to z czegoś wynika, sa procedury, kontrole, beneficjentom, którzy tu przychodza na doradztwo, powtarzam, że my też narzekamy, czasami trzeba pisać rzeczy oczywiste, zatączać dokumenty, które sq oczywiste. Oczywiście można te procedury uprościć, nie komplikować życia, wtedy będzie pomoc tatwiej dostępna (NR/J/06).

Osobiście wydaje mi sie to straszliwie nudne. Nawet te wnioski, jest to niesamowita walka z papierkami, wytycznymi, urzędami itd. [...] Mniej biurokracji [powinno być M.N.], mniej papierków i jakiś rozsądny system kontaktu zpetentami (L/G/01).

Jak wynika z przeprowadzonych wywiadów, w odniesieniu do spraw leżących na styku działania UE i obywatela (czyli praca krajowej administracji publicznej) respondenci krytykują urzędy i urzędników najniższych szczebli samorządu terytorialnego, ale rozciągają jednocześnie te pretensje na administrację rządową. Co zaskakujące, jeśli nawet samorząd, jak wskazują wywiady, zbiera dość pochlebne recenzje za chęć pomocy i spełnianie swych zadań wobec obywateli, to okazuje się, że Polacy odnoszą te opresyjne - zdaniem wielu - działania urzędników raczej do obowiązku wykonywania prawa stanowionego na poziomie centralnym (mityczna Warszawa), rzadko zaś łączą te kwestie z koniecznością realizowania zapisów prawa europejskiego bądź przestrzegania europejskich procedur ${ }^{16}$.

Jasne, Unia narzuca nam to prawodawstwo, prawo generalnie, które musi obowiązywać w catej UE. I to wiadomo, ale jeszcze w żadnych kraju nie widziatam, żeby ktoś tak gtupio wprowadzat te przepisy $w$ życie jak $w$ Polsce. To sq chore jakieś zamienniki, wymysty Polaków na to, żeby sobie samemu utrudnić życie. Jak ja jadę gdzieś, gdzie o tych naszych niby "polsko-unijnych" przepisach nikt nie styszat, a mam wielu znajomych, którzy prowadza biznesy po catej UE, to chyba jest cośnie tak. Dlatego przepisy w jakiś krajach albo sa nieistniejace, albo w o wiele bardziej logicznej, ludzkiej, wytagodzonej formie. To jest tak, jakby nasz wtasny kraj chciat nam jaką́s krzywdę zrobić, jakby w ogóle się z nami nie liczyt. Ja też mam świadomość, że chca z nas jak najwięcej pieniędzy wydusić, ale to też powinno mieć jakieś granice. Teraz są szcześliwi, bo mają Unię do obwiniania za wszelkie zto (Z/Z/10).

Często pojawiające się zarzuty wobec działalności administracji publicznej w naszym kraju dotyczą sfery polityki socjalnej państwa i samorządów, a zwłaszcza pomocy społecznej. Wielu respondentów zawraca uwagę na to, że nie jest ona ukierunkowana na pomoc najuboższym bądź wykluczonym, a mechanizmy działania pomocy społecznej doprowadziły do tego, że dla wielu rodzin stała się ona „sposobem na życie”. W efekcie problem wykluczenia społecznego nie jest konsekwencją niezależnych od ludzi czynników (np. choroba czy utrata pracy), a raczej wypadkową dobrowolnego

16 Problem ten chętniej dostrzegają raczej sami urzędnicy, dla których często Unia Europejska wraz z organami wyższego szczebla są „dyżurnymi chłopcami do bicia”, którymi mogą się zasłaniać w miarę potrzeby przed mieszkańcami. 
wyboru stylu życia (z zasiłków) oraz umiejętnością wykorzystania niedoskonałości systemu pomocy społecznej.

To, co mnie najbardziej denerwuje i téz się nie zmienito, to opieka spoteczna i to, jak ona dziata. Szlag mnie trafia, jak widzę, do kogo ona trafia. Sa ludzie, którzy nic nie robia, tylko dzieci ptodza i żyja z zasitków, i to nie matych, pewnie by nigdzie tyle nie zarobili. I dostaja pomoc z opieki, a inni ludzie, którzy by np. chcieli mieć dzieci, to się najpierw zastanowia, bo nie liczq na żadna pomoc zopieki. To się powinno zmienić (NR/J/05).

Bardzo zepsuta [ludzi - M.N.] opieka spoteczna, bardzo. Można pomóc, ale po co tym dzieciom basen, trampolina. Dajcie im chleba. Na ksiażki, prosze bardzo. [...] Najgorsza to jest ta opieka, to powinni zlikwidować. Za komuny tylko jedna taka babcia byta w matej chatupce, to jej opieka dawata. Ona byta faktycznie biedna, trzeba byto pomóc, ale tak jak dziśs? [...] A dziś te dziady mtode nic nie robia dla państwa. W zimie żeby chociaż chodnik odśnieżyli, nic, w lecie papierki pozbierali. A po co robic, jak opieka da? Kto będzie robit? Bardzo zepsuto państwo ludzi, a szczególnie ta opieka. Nie powinno tej instytucji być. W wyjatkowych przypadkach (Z/K/06).

Mnie wkurza to, że ludzie się nauczyli tylko brać od państwa. To nie może tak być, że jeden pracuje za 1500 ztotych, a inny różnych zasitków dostanie 1400. To po co pracować. To demoralizuje. Tak myślę, że unas opieka socjalna źle dziata. Ja rozumiem kupić biednej rodzinie ksiażki, leki, a nawet chleb, ale po co dawaćpieniadze. Trzeba takim ludziom pomagać szukać roboty, a nie uczyć, $\dot{z}$ e i tak dostanie. O, to mnie wkurza strasznie, bo wiem troche, jak to dziata, i jak tak Pan by po wioskach popytat, to na pewno petno takich ludzi Pan znajdzie, co tak powiedza. [...] Ja to myśle też, że wogóle tych przywilejów socjalnych jest za dużo. Kto to widziat, że by mtody chtop byt emerytem, tylko dlatego, żepolicjantem byt. To jest chore. Ja rozumie, że jak mu się cośstato na stużbie, to niech go państwo ubezpieczy i potem dobra rentę da na niego i dzieci, i tyle (S/SZ/07).

Nawet wypowiedzi pracowników ośrodków pomocy społecznej wyraźnie wskazują na błędy strukturalne w realizowaniu polityki społecznej państwa i zadań socjalnych samorządów. Jako osoby na co dzień działające w tej sferze, potrafią bardzo precyzyjnie wskazać słabe punkty jej funkcjonowania: $U$ nas to jeszcze bardziej tak by chcieli pieniqdze, że nie do końca prace, tylko pieniadze. [...] A w pierwszym etapie to byto tak, że ona chce, chce, zrobi. Choć nie mówita „ja chcę", tylko "chciatoby się”, "posztoby się" (Z/Z/04). $\mathrm{Z}$ przeprowadzonych rozmów wynika, że największymi problemami, z jakimi się spotykają w swej pracy na poziomie lokalnym, są:

- oczekiwanie przez zainteresowanych przede wszystkim pomocy finansowej, a nie materialnej;

- akcyjność działań (jeśli przyjdzie polecenie);

- permanentne uchylanie się zainteresowanych przed szkoleniami przekwalifikującymi lub wręcz przed podjęciem pracy;

- brak spójnej wizji działania pomocy społecznej i marnotrawstwo środków finansowych (również pochodzących z UE, jeśli są przeznaczone na konkretny projekt nietrafiony ze względu na specyfikę regionu).

Co istotne, wskazane tu problemy najczęściej potwierdzają tylko cytowane powyżej krytyczne spostrzeżenia respondentów odnoszące się do faktu, iż większość osób, 
z którymi mają do czynienia, jest bezrobotna z wyboru, a kontakt z pomocą społeczną i jej pracownikami jest sposobem na życie.

Dodatkowo wspomnieć również trzeba, że osoby, z którymi udało się przeprowadzić rozmowy, a które odbyły różnego rodzaju szkolenia przekwalifikujące organizowane bądź to przez Powiatowe Urzędy Pracy, bądź też na które skierowani zostali przez gminne ośrodki pomocy społecznej, wskazywały rzeczywiście na bezsensowność tego typu przedsięwzięć.

Zazwyczaj urzad przymusza ludzi, żeby wzięli udziat w szkoleniu, bo jest to dobrze widziane przy dofinansowaniu firmy. Widzę też, jak wysyta się bezrobotnych na różne szkolenia, które i tak na nic się zdaja, bo nie uczy się tych ludzi rzeczy, które później sa pomocne w szukaniu pracy. No jasne, budowlańców z kursem na ksiegowego albo cośtakiego. Kompletnie bez pomyślunku jest ten caty system szkoleń (NS/NS/02).

Nic, sa tylko ulotki i plakaty, które niewiele mi mówia. Dużo obrazków, mato konkretów. Jest plakat, który mówi, że jest dla mnie szkolenie z jakiejś aktywizacji. Jakiej aktywizacji, o co w ogóle chodzi? Co oni będa mnie tam uczyć? Ja już jestem za stary na takie nauki. Panie, ja mam fach w ręku, a oni chca mnie komputera uczyć. Przecież to jest jakaś paranoja. Ja przez cate życie bytem mechanikiem i naprawiatem maszyny rolnicze, ciagniki, Panie, traktory, nie firmy. Ja pracowatem, a nie bawitem się w firmy (L/G/04).

No niby tak podszkolić. Nawet to byto fajne i niby miato jakiśsens. [...] Byto tak profesjonalnie i schludnie wszystko zrobione. Poczęstunek i w ogóle. Na początku, przyznam się, $\dot{z}$ e posztam gtównie dla jedzenia, [...] że tylko chodzić, że dostaniemy papierek i darmowe obiady. Kto by nie skorzystat? [...] Okazato się na samym już końcu, że te wszystkie takie zaświadczenia i papierki z tych szkoleń to można sobie o [wulg.] rozbić. No i co, że ja to mam, skoro pracodawca tego nie uznaje. Dla nich to jest takie troche dla picu. Szkolenie dla szkolenia, bez praktycznego doświadczenia. Trochę nie halo pod tym względem. Niby fajnie, ale niepraktycznie. Gdyby MOPS zagwarantowat nam prace albo jakieś ptatne praktyki później, to by byta inna sprawa. [...] Osobiście wydaje mi się, że szkolenia bardziej sa dla tych, którzy szkola i to organizują, aniżeli dla tych, którzy maja się uczyć (Z/Z/12).

\section{WNIOSKI}

Przechodząc do wniosków, które należy wyciągnąć z przeprowadzonych w ramach projektu rozmów i wywiadów pogłębionych, wskazać należy przede wszystkim na ciągle bardzo wysokie poparcie społeczeństwa polskiego dla obecności naszego kraju w Unii Europejskiej i dla integracji europejskiej jako projektu w ogóle. Choć przeprowadzane inną metodologią, to wskazują na to zarówno przytaczane badania CBOS, jak również statystyki publikowane przez Eurobarometr, z których wynika, że zaufanie Polaków do UE jest znacznie wyższe od średniej społeczeństw wszystkich państw członkowskich ${ }^{17}$. Co nie zmieniło się od czasów przedakcesyjnych, postawy proeuropejskie reprezentują

17 Zob. np.: Eurobarometr Opinia publiczna w Unii Europejskiej, Standardowy Eurobarometr 80 / jesień 2013, [online] http://ec.europa.eu/public_opinion/archives/eb/eb80/eb80_pl_pl_nat.pdf, dost. 10.012015 
osoby lepiej zarabiające i lepiej wykształcone, a przede wszystkim respondenci, których ze względu na pozycję społeczną na poziomie gminy moglibyśmy nazwać członkami lokalnych elit (urzędnicy, wykonujący wolne zawody, pracownicy kultury i oświaty, działacze stowarzyszeń i osoby aktywne społecznie $)^{18}$.

Badania zespołu pracowników Instytutu Europeistyki UJ nie tylko potwierdzają te spostrzeżenia, ale równocześnie ujawniają dychotomię między stosunkiem Polaków do UE a wynikającą z uczestnictwa naszego kraju w strukturach UE koniecznością przyjęcia wspólnej europejskiej waluty. Na obecnym etapie większość respondentów jest wobec niej wręcz niechętna, co w dużej mierze wynika z dramatycznie niskiego poziomu wiedzy ekonomicznej Polaków i wymaga poważnej refleksji, jeśli chodzi o politykę informacyjną rządu i Narodowego Banku Polskiego w tym zakresie.

Bez wątpienia ten pozytywny stosunek do Unii Europejskiej jest pochodną bezprecedensowego napływu funduszy europejskich do naszego kraju, i to głównie im projekt integracyjny zawdzięcza tak istotne poparcie. Smutną konstatacją jest natomiast fakt, iż w związku z powyższymi uwagami Polacy (poza nielicznymi przypadkami) nie dostrzegają żadnej głębszej idei przyświecającej integracji europejskiej, a literalnie żaden respondent nie wspomniał nawet o największym bodaj osiągnięciu zjednoczonej Europy, jakim jest pokój i brak konfliktów zbrojnych między państwami się integrującymi.

Zauważyć należy, iż dla osób w wieku 40+ punktem odniesienia dla obecności Polski w UE jest raczej okres PRL, natomiast czas między rokiem 1989 (początek zmian ustrojowych) a rokiem 2004 (wejście Polski do UE) jest swego rodzaju mentalną ,"zarną dziurą" i wydaje się ulegać zatarciu w świadomości respondentów. W efekcie wielu badanych okres 1989-2003 kojarzy z kontynuacją czasów realnego socjalizmu, a wejście Polski do UE zdaje się być dopiero właściwą datą przełomową w najnowszej historii Polski.

Dla młodszych respondentów właściwie nie istnieje dzisiaj „świat bez Unii”, i to oni w największym stopniu są jej beneficjentami. Oni też wskazują częściej w odpowiedziach na takie kwestie, jak swoboda podróżowania czy brak kontroli na granicach. Zdecydowana większość respondentów w ogóle nie wyobraża sobie możliwości wyjścia Polski z Unii Europejskiej, deklarując, że gdyby doszło do referendum w tej sprawie, głosowaliby przeciwko wystąpieniu z niej ${ }^{19}$. Ze zdziwieniem wręcz spotyka się wśród osób młodych pytanie o możliwość rozpadu UE z przyczyn od nich niezależnych (np. No to jesteśmy w gtębokiej [wulg.] i mamy problem. Wptynętoby to na nas katastrofalnie (L/G/03)). Osoby starsze jednak reagują spokojniej i zauważają, że Polska i tak dałaby sobie radę, tak jak wcześniej, kiedy do niej nie należała.

W nawiązaniu do poruszanych $\mathrm{w}$ artykule kwestii związanych z zadowoleniem mieszkańców z pracy urzędów gmin i urzędników dominuje opinia o znacznym

18 Por.: M. Galent, M. Natanek, E. Turyk, Interesy, szanse i zagrożenia, kompetencje cywilizacyjne a postawy wobec integracji, [w:] Polska lokalna wobec integracji..., s. 125-171.

19 Jednocześnie jednak dopuszczają możliwość rozpadu strefy EURO, co pozostaje logiczną konsekwencją negatywnego stosunku do planu przyjęcia wspólnej waluty w ogóle. 
polepszeniu się obsługi w urzędach w zakresie kultury pracy i stosunku do osób załatwiających sprawy urzędowe ${ }^{20}$. Nie zmienia to tego, że mieszkańcy coraz częściej narzekają na cykliczność działań władz gminnych, która uzależniona jest według nich od kalendarza wyborczego. Bez wątpienia najpoważniejszy pojawiający się zarzut dotyczy oderwania elit lokalnych od codziennych problemów mieszkańców i przede wszystkim braku konsultacji społecznych przed podjęciem decyzji w ważnych dla nich sprawach. W tym kontekście warto zwrócić uwagę na trzy kwestie:

Po pierwsze, mieszkańcy zdają sobie sprawę z trudności w organizacji masowych zebrań wiejskich i własnej bierności jako obywateli. Stąd też coraz częściej (zwłaszcza w grupie wiekowej 18-45 lat) pojawiają się propozycje wykorzystania Internetu jako narzędzia komunikacji z obywatelami w postaci różnego rodzaju sond i ankiet oraz ogłoszeń o ważnych z punktu widzenia mieszańców inwestycjach (np. SZ/Ł/04, NR/J/04).

Po drugie, nawet w środowiskach wiejskich i małomiasteczkowych mieszkańcy coraz częściej (choć z ogromnymi wątpliwościami) dają wyraz swojemu zainteresowaniu budżetem partycypacyjnym (obywatelskim), o którym słyszą coraz częściej w mediach lokalnych i regionalnych. Tego typu bezpośredni udział w procesie podejmowania decyzji o wydatkowaniu wspólnych środków daje ogromne szanse na przełamanie bierności w zachowaniach politycznych i obywatelskich (np. L/G/06, L/G/07, NS/NS/04).

Po trzecie wreszcie, w zgodnej opinii społeczności lokalnych ogromna rola w tym względzie przypada sołtysom, którzy właściwie wyrastają na jedyne ogniwo kontaktu między władzami gminy a jej mieszkańcami. $Z$ jednej strony są więc postrzegani jako osoby roznoszące nakazy podatkowe, z drugiej zaś wyrastają na jedynych liderów, którzy potrafią porwać za sobą współmieszkańców i wzbudzić w nich jakąkolwiek potrzebę oddolnej inicjatywy (np. Z/S/02, S/SZ/03)

Wynikiem zaistnienia pierwszych dwóch wspomnianych tu czynników jest w zgodnej opinii przepytywanych swoistego rodzaju matnia: władza nie organizuje konsultacji społecznych i nie kontaktuje się z mieszkańcami, ponieważ ludzie są bierni; ludzie zaś są bierni, ponieważ władza i tak nie pyta ich o zdanie. Bez względu na to, gdzie owo błędne koło ma swój początek, wydaje się jednak, że to na samorządzie powinien spoczywać obowiązek inicjowania dialogu społecznego, perswazji i wykształcenia w obywatelu postaw prospołecznych i propaństwowych.

Zupełnie innym, a wskazywanym przez respondentów często problemem, któremu w tekście poświecono dużo miejsca, jest jeszcze coraz częściej spotykana obawa i niechęć urzędników do podejmowania samodzielnych decyzji, nawet jeśli pozwala na to prawo. Panuje więc powszechne przekonanie, iż na każde działanie muszą oni mieć przysłowiową "podkładkę". Skutki wprowadzenia takich metod zarządzania (samorządem i państwem) mogą jednak daleko wykraczać poza przysłowiowe już narzekania obywateli na urzędników i urzędy wszystkich szczebli. Po pierwsze, co oczywiste, rozrost administracji i długi czas obsługi obywateli, a tym samym podniesienie kosztów działalności państwa i firm. Po drugie - i najważniejsze - w efekcie wszystkie

20 Zdaniem wielu przepytywanych świadczyć o tym ma sam fakt, iż coraz rzadziej używa się słowa „petent”, a coraz częściej - „klient”. 
wskazane wcześniej i krytykowane praktyki (biurokracja, procedury itp.) obciążają przede wszystkim działania państwa polskiego en bloc i kładą się cieniem na jego wizerunku, obniżając jednocześnie zaufanie obywateli do jego instytucji.

Próbując odpowiedzieć na zadane w tytule artykułu pytanie, można zaryzykować twierdzenie, że społeczności lokalne wykorzystały (i nadal wykorzystują) szansę, jaką daje obecność naszego kraju w UE. Na pewno nie można mówić, iż nadal mamy do czynienia z marazmem, co nie zmienia postaci rzeczy, iż wiele jest jeszcze do naprawienia, jeśli chodzi o funkcjonowanie struktur państwa i demokracji na poziomie lokalnym w naszym kraju. Szczęśliwie więc ten marazm sprzed kilkunastu lat coraz częściej zastępowany jest swego rodzaju fermentem (w pozytywnym znaczeniu tego słowa), a mieszkańcy coraz częściej dzięki swym inicjatywom stają się świadomymi obywatelami małych ojczyzn, o czym świadczyć mogą chociażby zaskakujące w wielu miejscach wyniki ostatnich wyborów samorządowych z jesieni $2014 \mathrm{r}$.

\section{BIBLIOGRAFIA}

CBOS, Komunikat z badań nr 52/2014, 10 lat cztonkostwa Polski w Unii Europejskiej, Warszawa, IV 2014.

CBOS, Komunikat z badań, BS/115/2004, Stosunek do cztonkostwa w Unii Europejskiej i pozycja Polski w zjednoczonej Europie, Warszawa, VII 2004.

CBOS, Komunikat z badań, BS/66/2008, Bilans czterech lat integracji Polski z Unia Europejska, Warszawa, IV 2008.

Eurobarometr Opinia publiczna w Unii Europejskiej, Standardowy Eurobarometr 80 / jesień 2013, [online] http://ec.europa.eu/public_opinion/archives/eb/eb80/eb80_pl_pl_nat.pdf.

Galent M., Natanek M., Turyk E., Interesy, szanse i zagrożenia, kompetencje cywilizacyjne a postawy wobec integracji, [w:] Polska lokalna wobec integracji europejskiej, red. Z. Mach, D. Niedźwiedzki, Kraków 2001.

Kulesza M., Transformacja ustroju administracyjnego Polski (1990-2000), „Studia Iuridica” 2000, t. 38.

Natanek M., Niedźwiedzki D., Kompetencje spoteczeństwa polskiego w zakresie kultury europejskiej, czyli o nieprzygotowaniu do integracji z Europa, [w:] Kregi kompetencji i perspektywy poznawcze, red. J. Goćkowski, P. Kisiel, Kraków 1999.

Natanek M., Niedźwiedzki D., Kulturowe kompetencje Polaków a integracja europejska, [w:] Integracja europejska w oczach Polaków, red. Z. Mach, Kraków 1998, Studia i Analizy Fundacji Międzynarodowe Centrum Rozwoju Demokracji, 5.

Obwieszczenie Państwowej Komisji Wyborczej z dnia 9 czerwca 2003 r. o wyniku ogólnokrajowego referendum w sprawie wyrażenia zgody na ratyfikacje Traktatu dotyczacego przystapienia Rzeczypospolitej Polskiej do Unii Europejskiej, Dz. U. 2003, nr 103, poz. 953.

Polska lokalna wobec integracji europejskiej, red. Z. Mach, D. Niedźwiedzki, Kraków 2001.

Polskie 10 lat w Unii - raport, Ministerstwo Spraw Zagranicznych RP, Warszawa 2014.

Traktat [...] dotyczący przystąienia Republiki Czeskiej, Republiki Estońskiej, Republiki Cypryjskiej, Republiki Eotewskiej, Republiki Litewskiej, Republiki Wegierskiej, Republiki Malty, 
Rzeczypospolitej Polskiej, Republiki Stowenii i Republiki Stowackiej do Unii Europejskiej, podpisany w Atenach w dniu 16 kwietnia 2003 r., Dz. U. 2004, nr 90, poz. 864.

Traktat ustanawiajacy Wspólnotę Europejska, tekst skonsolidowany (uwzględniający zmiany wprowadzone traktatem z Nicei), Dz. U. UE C 325, 24 XII 2002.

Wywiady pogłębione przeprowadzone w ramach projektu „Polska lokalna wobec integracji europejskiej - dekada doświadczeń" finansowanego przez Narodowe Centrum Nauki (2011/03/B/HS6/01163).

Dr Mirosław NATANEK - historyk (UJ) i europeista (Université Paul Valery Montpellier III). Adiunkt w Instytucie Europeistyki Uniwersytetu Jagiellońskiego. Jego zainteresowania naukowe koncentrują się przede wszystkim na historii integracji europejskiej i jej samorządowym wymiarze oraz na międzynarodowej współpracy europejskich samorządów lokalnych. Szczególnym obszarem badawczym jest również dla niego działalność Rady Europy, gdzie odbył dwukrotnie staże badawcze. Jest autorem kilku artykułów z tego zakresu, w tym w języku angielskim, oraz współautorem raportów eksperckich dla Rady Europy. Wykładowca i visiting professor m.in. na Université Catholique de Louvain, Univerzita Mateja Bela (Banská Bystrica), Pázmány Péter Katolikus Egyetem (Budapest), Univerzita Palackého (Olomouc). 